PRIVATE SAVING IN THE UNITED STATES:

$1950-85$

Patric H. Hendershott

Joe Peek

Working Paper No. 2294

NATIONAL BUREAU OF ECONOMIC RESEARCH 1050 Massachusetts Avenue

Cambridge, MA 02138

June 1987

An earlier version of this paper was presented at the Income and Wealth Conference on the Measurement of Saving, Investment and Wealth, March 28 , 1987. Joe Peek thanks the Federal Reserve Bank of Boston, where he is a visiting economist, for financial support and George Houlihan and Edward Lyon for their assistance with the graphics. The research reported here is part of the NBER's research program in Taxation. Any opinions expressed are those of the authors and not those of the Federal Reserve Bank of Boston, the Board of Governors of the Federal Reserve System, or the National Bureau of Economic Research. 
NBER Working Paper \#2294 June 1987

Private Saving in the United States: $1950-85$

\begin{abstract}
$\underline{\text { ABSTRACT }}$
The official personal and private saving statistics contain a number of conceptual measurement errors. In this paper we develop and analyze personal and private saving measures adjusted for the difference between income tax payments and actual liabilities, saving via net purchases of government pension assets (including social security) and consumer durables, and that part of after-tax interest income attributable to inflation.

We find that the adjusted personal and private saving rates in recent years are only slightly below their post-1950 averages, not at all time lows as reported in the official NIPA statistics. Furthermore, over the past 35 years, personal saving has been more volatile and corporate saving less volatile than the official measures. Also, the inflation premium corrections remove the negative correlation between personal and corporate saving. That is, the often corporate saving is due solely to meation the official measures of personal and Finally, the decrease in federal government continuation of a 30-year trend continuation of a 30-year trend, not a one-time aberration.
\end{abstract}

Patric H. Hendershott Hagerty Hall The Ohio state University 1775 College Road Columbus, Ohio (614) 292-0552
43210

\author{
Joe Peek \\ Department of Economics \\ 141 Carney Hall \\ Boston College \\ Chestnut Hill, MA 02167 \\ (617) 552-3686
}




\section{Private Saving in the United States: $1950-85$}

\section{Patric H. Hendershott and Joe Peek}

Many researchers define saving synonymously with the change in real wealth: net worth at the end of the period less net worth (revalued to current prices) at the beginning of the period. ${ }^{1}$ saving, then, would be the change in real resources available for future consumption. ${ }^{2}$ while this change is certainly an important variable worthy of serious investigation, the ex post change in real wealth in most periods is largely the result of unexpected wealth changes (stock market gains or losses, housing and land booms, etc.). That is, the change in real wealth is generally dominated by real asset price changes, not planned decisions to increase or decrease the accumulation of wealth. ${ }^{3}$

Alternatively, and more customarily, saving is defined in flow terms as income less consumption and taxes. Given initial wealth and expectations regarding after-tax income and real capital gains, saving and consumption are simultaneously determined. Movements in saving rates, then, lead observers to conclusions regarding the impacts of policies on behavior. For example, a decline in the personal saving rate immediately following both the introduction of IRA accounts and a sharp increase in real interest rates might lead one to conclude that IRAs have not encouraged saving and that saving is highly interest inelastic. However, if the saving decline were due to mismeasurement, then one or both of these conclusions could be incorrect.

The proper conceptual measurement of personal and private saving is the subject of this paper. The official National Income and Product Accounts (NIPA) saving series are increased to reflect saving via net purchases of 
The need for these adjustments is well understood (see Blades and Sturm 1982, for example); our intended contribution is the careful implementation of the adjustments and analysis of the resulting adjusted saving series.

The plan of the paper is as follows. We begin with a discussion of the problems in the official measurement of personal and corporate saving and then propose adjustments to correct the official series. Next, the adjusted personal and private saving rates are computed and analyzed. Finally, personal saving equations are estimated on annual data for the 1952-85 period to verify that the proposed conceptual adjustments are consistent with the data, i.e., the estimated coefficients on the adjustments are significantly different from zero and not significantly different from their expected values (plus or minus unity). While such macro relationships are subject to the Auerbach-Kotlikoff critique (1986), the estimates seem appropriate for the task at hand.

A number of interesting findings are obtained. First, correctly measured personal and private saving rates in recent years (1983-85) are 58 (not percentage points) below their averages since 1950, not, as reported in the official statistics, at all time lows and 208 below their post-1950 averages. Second, the personal saving rate has been more volatile over the past 35 years than the official data indicate. Third, corporate saving has been less volatile, as Auerbach (1982) found. Fourth, the often observed negative correlation between personal and corporate saving is due solely to measurement error (the negatively correlated inflation premia in the two saving components). Fifth, both personal and private saving have rebounded somewhat in recent years (1983-85), again in contrast to the official series. 


\section{Adjustments to Personal and Corporate Saving}

Saving is generally calculated residually as the difference between income received and certain outlays made. For personal saving, income received includes wages and salaries, dividends, rents, interest, and transfers; for business saving, income is profits. Outlays for both include consumption expenditures ("dividends" and "depreciation" for businesses), taxes and interest paid. For our purposes, it is convenient to define saving as

$$
\text { SNIA }=\text { INC }- \text { CEXP }- \text { TAX }- \text { NINTP, }
$$

where SNIA is NIPA saving, INC is income other than interest received, CEXP is consumption expenditures, TAX is tax payments and NINTP is net interest payments (interest paid less interest received). Thus, measurement errors in income or in any of the terms subtracted from it will be embedded in saving, dollar-for-dollar. Significant conceptual errors are generally made in the measurement of personal income, consumption, and net interest income of both persons and businesses. Before turning to the adjustments necessary to correct these errors, we explain why and how noncorporate business saving is included in personal saving rather than being aggregated with corporate saving into a broad total business category.

A. Integration of Households and Noncorporate Businesses Private saving is the sum of household and business saving, but the components of saving reported in the NIPA are personal and corporate saving. That is, saving of noncorporate businesses is integrated with that of households into personal saving. Thus corporate and noncorporate business saving are treated decidedly different. 
In the NIPA, two categories of noncorporate nonfinancial business are delineated: sole-proprietorships-and-partnerships and other-private-business. The first category is further subdivided into farm and nonfarm, the second into real estate and other. The other-private distinction is apparently for household "portfolio" rental activities, such as owning a small duplex or shares in rental or oil and gas partnerships. Such portfolio activities, being analogous to purchases of REITs and other corporate shares, certainly should be integrated with household personal accounts. However, farm and nonfarm sole proprietorships and partnerships are businesses, and the retention of earnings within these enterprises seems no different than the retention within corporations. ${ }^{4}$

Unfortunately, the division of proprietorship and rental income between wages earned and capital income is unclear. Moreover, following the residual definition of saving as income less outlays, one would need to allocate household expenditures, taxes, and interest paid between personal and business activities. Given the impossibility of separating any of the right-hand side variables in equation (1) into their personal and business components, "household" and noncorporate business income and expenses are fully integrated and the resulting saving measure is labelled personal saving.

Table I illustrates the effects of integration on the 1985 household balance sheet. The underlying data, which include market values of tangible assets and corporate equity, are from the Board of Governors (1986). In these data, nonfinancial business activity is divided among corporate, farm (including a small amount of corporate), and nonfarm noncorporate. Longer-term financial asset and liability series have been converted from par to market values (the data in parentheses are par values) using updated bond price indices from Eisner and Pieper (1984). The first column in the table contains 


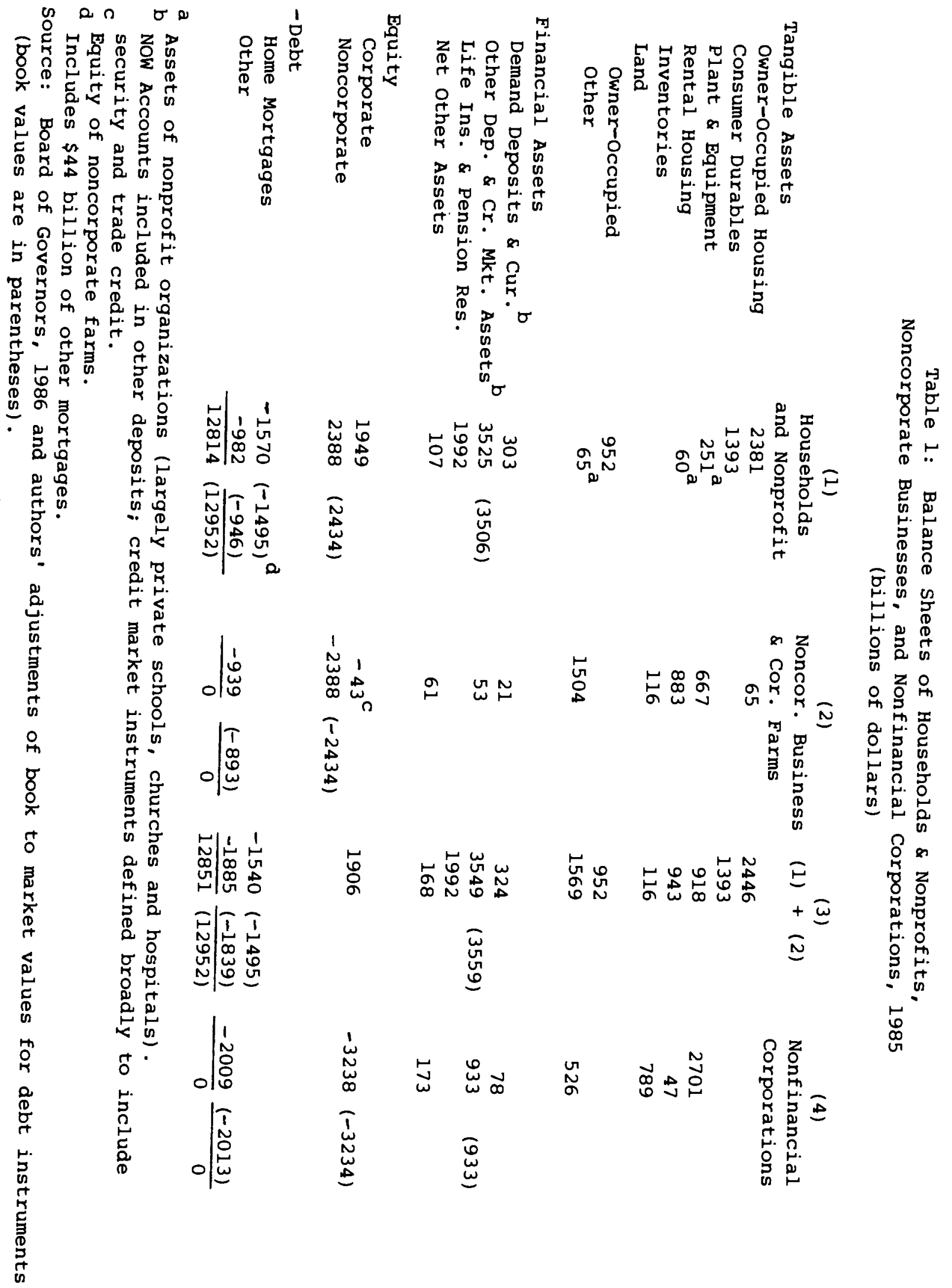


the basic household data (plus nonprofit organizations and personal trusts); the second column is the noncorporate data (plus a small amount for corporate farms); and the third column is the integrated household-noncorporate accounts. For comparison purposes, the data for nonfinancial corporations (excluding farms) are listed in the fourth column. As can be seen, the basic household sector has about $\$ 5$ trillion in tangible assets (two-thirds is owner-occupied housing and the land it is on and over three-quarters of the rest is consumer durables), almost $\$ 6$ trillion in financial assets, nearly $\$ 4 \frac{1}{2}$ trillion in corporate and noncorporate equity, and $\$ 2 \frac{1}{2}$ trillion in debt ( $\$ 1 \frac{1}{2}$ trillion of which is mortgages). Household net worth is thus about $\$ 13$ trillion.

The nearly $\$ 2 \frac{1}{2}$ trillion of household noncorporate equity represents claims on over $\$ 3$ trillion of tangible assets, as well as nearly a trillion of net debt. Almost half of the tangible assets is land, largely for farming, and half of the remainder is rental housing. Thus, the merged householdnoncorporate balance sheet in column 3 looks far different than the basic household balance sheet.

The balance sheet of nonfinancial corporations differs greatly from that of nonfinancial noncorporate business, owing to the large role of corporations in manufacturing and their small roles in rental housing (less than 5 percent of the stock) and farming (which is in the noncorporate accounts anyway). In addition, corporations have far larger holdings of financial assets than do noncorporate businesses. Noteworthy is the large difference between the net worth of corporations computed residually from the balance sheet $(\$ 3238$ billion) and the market value of household corporate equity holdings ( $\$ 1906$ billion). About half the difference reflects indirect household equity 
holdings via their life insurance and pension reserves. The other half is the oft noted difference between the replacement cost and market value of corporate assets (Tobin's q being less than unity).

\section{B. Conceptual Saving Adjustments}

Household retirement transactions with the private sector are accounted for correctly in the computation of saving. A dollar "contributed" to a retirement plan is a dollar of income not consumed and thus a dollar of saving. similarly, a dollar of interest earned on retirement accounts and not consumed is a dollar of saving. Finally, a dollar of benefits received and not consumed does not affect measured saving; cumulated wealth is simply being transferred from one asset form to another. Unfortunately, the treatment of government retirement accounts in the official NIPA saving statistics is far different. 5 A dollar contributed to a government retirement plan or social security, or accrued as interest on either, is not included in personal income and thus is not counted as a dollar of saving. Also, all benefits received are classified as income (transfer payments), and thus raise saving, even though a part of benefits are certainly a return of principal or interest. Because contributions and interest earned exceed benefits paid in a growing retirement system, the net result of this asymmetric treatment is an understatement of income and thus of saving.

Theoretical models of consumption and saving behavior (for example, the Life Cycle Hypothesis, the Permanent Income Hypothesis, and their derivatives) are stated in terms of the consumption of service flows. These flows, rather than consumption expenditures, are a determinant of household utility. Thus saving is the deferral of consumption of service flows. To be consistent with theory, only the consumption of service flows should be subtracted from income; the component of consumer expenditures representing net investment in consumer 
durable goods should properly be considered saving. Official NIPA measures of personal saving, however, are based upon the subtraction of all consumption expenditures, rather than service flows only, and thus understate personal saving.

A major problem with both household and business saving statistics is the measurement of interest income received and paid during inflationary periods. The expectation of net capital losses on fixed-dollar financial assets due to inflation leads to the incorporation of an inflation premium in nominal interest rates to compensate investors for the expected losses. Part of household and business stocks of fixed-dollar assets are being converted into flows (the inflation premium component) that are recorded inappropriately as interest income received. Conversely, part of household and business stocks of financial liabilities are being eroded, and the associated inflation premium is wrongly recorded as interest paid. These inflation premia obviously rise with the inflation rate. Because households are net creditors, the overstatement of interest paid is less than the overstatement of interest received. Thus personal saving is overstated. Because corporations are net debtors, corporate saving is understated.

The above discussion is summarized in Table 2: line 1 contains the official measure of the various variables used to compute saving, line 2 lists the conceptual error, line 3 indicates the effect of the error on the saving measures, and line 4 states the required corrections to the official series. Note that business income is defined to include the NIPA capital consumption and inventory valuation adjustments. 6 


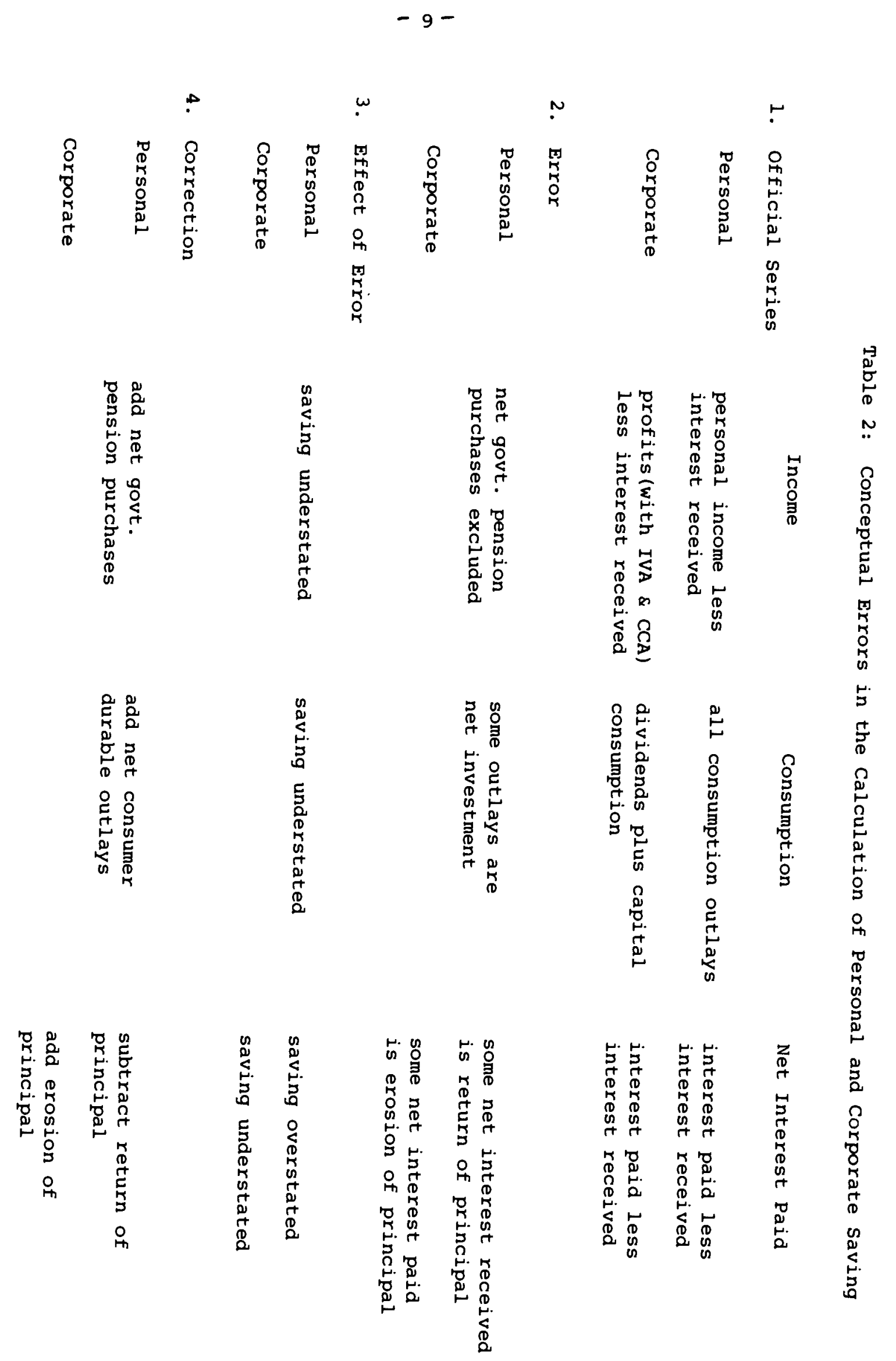


One final point: corporate income taxes are measured on an accrual basis, while personal income taxes are on a cash basis. Because individuals plan consumption and saving over a period of years, not weeks, the appropriate measurement convention is the accrual method (see Peek 1982). Thus household tax payments need to be converted to an accrual basis.

C. Actual Consumption, Income and Tax Adjustments

Some of the adjustments to the official saving series are straight-forward. For the personal consumption mismeasurement, net (of depreciation) purchases of consumer durables (SCDUR) are added; ${ }^{7}$ for the government employee life insurance and pension adjustment to personal income, net purchases of government life insurance and pension reserves (SGPEN) are added. Each of these series is available from the Federal Reserve Flow of Funds Accounts. As for social security, Blades and Sturm (1982) argue that contributions plus accrued interest less benefits should be added to personal saving. ${ }^{8}$ This procedure seems appropriate if social security promises a fair market return. However, if social security is a bad investment, then some of the contribution should be viewed as a tax paid, and if social security is an extraordinary investment, then households are receiving a transfer payment above and beyond their contribution. More generally, the addition to personal saving should be

$$
(1+B) \operatorname{CON}+i^{m} \mathrm{ACCON}-\mathrm{BENE},
$$

where CON is current contributions, ACCON is the implicit cumulated stock of contributions and past interest earned, BENE is benefits paid, $i^{m}$ is the fair market interest rate, and the sign (and magnitude) of $B$ depends on how much the promised return on social security, $i^{s}$, exceeds or falls short of the market rate of return:

$$
B \frac{>}{<} 0 \text { as } i^{s} \geq i^{m} .
$$


Unfortunately, $B$ and ACCON are not known. Thus, our adjustment for social security is more conjectural than our other adjustments.

Munnell, speculating that households might view social security old-Age and Survivors Insurance (OASI) contributions as saving, added them to official saving (1977, Figure 6-1, p. 115). Adding contributions to saving is the correct adjustment if one assumes that the transfer component of contributions, $B C O N$, plus accrued interest at the market interest rate equals benefits received. This equality may have held approximately during the 1950s, 1960s and 1970s. For example, the equality would hold if contributions equaled benefits (approximately correct since the middle 1950s), accumulated contributions equalled 25 times benefits paid, the market interest rate were 0.03 , and the return on social security were perceived to be sufficiently above market that 25 cents of transfers accompanied every dollar of contributions ( $\beta$ $=0.25)$. We adopt this assumption as a working hypothesis and thus add OASI contributions (both employee and employer) to personal saving, denoting the adjustment as SSSEC. The contributions data are from U.S. Department of Health and Human Services, 1986, Table 15, p. 81.

In the late 1970s and early 1980s, the need to revise benefits downward and contributions upward (lower $i^{\mathbf{s}}$ relative to $i^{m}$ and thus lower $B$ ) became clear. Declining birth rates, increased life expectancy, and likely slower real growth were all contributing factors (McSteen, 1985). Legislation in 1983, which advanced scheduled tax rate increases, taxed half of benefits above a fixed nominal total income level, and raised the retirement age for future retirees, confirmed expectations of a reduced $B$. To account for a decline in $B$, we freeze the OASI adjustment at its 1980 real level of $\$ 119.5$ billion (SSSEC80) for the entire 1981-85 period. The difference between SSSEC and SSSEC80 is roughly $\$ 10$ billion in 1981-83 and $\$ 35$ billion in 1984-85. 
Figure 1 contains SGPEN, SGPEN plus SSSEC (or SSSEC80), and the sum of SGPEN, SSSEC (or SSSEC80) and SCDUR in constant 1982 dollars. Net purchases of government life insurance and pension reserves and social security OASI contributions have risen monotonically from $\$ 6$ and $\$ 10$ billion, respectively, in the early 1950 s to $\$ 60$ and $\$ 155$ billion $(\$ 120$ billion with the 1980 s adjustment) in the middle 1980s. The net durables series has a strong cyclical component as well as an upward trend. On a trend basis, the series has risen, erratically, from $\$ 30$ billion in the early 1950s (1950 and 1951 data were greatly affected by the outbreak of the Korean war) to $\$ 90$ billion in the middle 1980s.

The personal income tax timing adjustment (STAX) is the difference between NIPA federal personal income tax payments and federal personal income tax accruals as calculated by the Bureau of Economic Analysis. The latter series is based on individual income tax return data adjusted for liability changes due to audits, amended returns, and additional assessments. ${ }^{9}$ Most of the difference between payments and accruals (which has fluctuated between -7 and +16 billion 1982 dollars) arises because the net refund for tax year $t$ is included in the liabilities of year $t$ and in the cash payments of year $t+1$. The major fluctuations in the net refund series are due to differences in the timing and magnitude of the changes in income tax rates and the corresponding withholding schedules.

\section{Inflation Premium Adjustments}

A simple specification of the inflation premium is the product of the anticipated inflation rate and the stock of net fixed-income assets (see, for example, Jump 1980). ${ }^{10}$ This specification implies immediate, complete adjustment of interest income to the current anticipated inflation rate. In fact, net interest income included in personal saving did not adjust anywhere near this rapidly during the $1965-79$ period of rising inflation. First, 
binding interest rate ceilings on at least some demand and savings accounts have existed in the United States since the early 1960s. Once these nominal interest rate ceilings became binding, the monetary interest payments on such assets incorporated an additional inflation premium only as rapidly as ceiling interest rates were raised. Second, while additional interest from financial institutions was imputed to individuals when interest rates (inflation) rose, imputed interest responded sluggishly to interest rate increases. Third, a significant part of fixed-coupon household assets and liabilities are longterm. For these instruments, coupon receipts/payments adjust to an increase in interest rates only over time as new bonds are issued to replace maturing bonds (yields adjust immediately via a decline in the market price of the instruments). Thus, the inflation component of NIPA interest income and expenses substantially lagged the increase in the anticipated inflation rate. (The adjustment to a decrease in inflation will occur more rapidly to the extent that refinancing results in high coupons being replaced by lower coupons and deposit rate floors do not exist.) Another problem with this simple specification of the inflation premium is that the tax liabilities incurred on monetary interest income are ignored: only the net-of-tax inflation premium component is available to individuals to maintain the real value of their net financial assets during an inflationary period. If the real value falls by more than the net-of-tax premium, then an uncompensated real capital loss is incurred.

Similar arguments can be made against such a specification for the inflation premium in business net interest paid. Interest payments increase sluggishly when interest rates rise because some debt is long term. Moreover, interest is fully tax deductible, so the cost of the erosion of outstanding debt is only the net-of-tax inflation premium. 
We have constructed inflation premium adjustments for personal and corporate saving that are based on the relevant measures of NIPA net interest income (persons) and net interest expense (businesses). Table 3 presents the components of the net interest measures for 1985. Household net interest received equals monetary interest paid to persons and noncorporate businesses, plus imputed interest received by persons from life insurance carriers and private noninsured pension plans, less monetary interest paid by consumers (excluding mortgage interest on owner-occupied housing and nonprofit capital). Mortgage interest on owner occupied housing and nonprofit capital is excluded in this calculation because this interest is included in both personal income and consumer expenditures (housing services) and thus nets out in the calculation of personal saving. Imputed interest received by persons from banks, credit agencies, and investment companies is omitted because it, too, is included in both personal income and consumer expenditures (in the latter as services furnished without payment by financial intermediaries). Finally, imputed interest received by noncorporate business is not included in their net income (and hence in personal income), being both an income item and an expense item and thus irrelevant to the saving calculation. Turning to nonfinancial corporations, their net interest paid is simply monetary interest paid less monetary interest received. Imputed interest received by nonfinancial corporations from financial institutions is omitted because it is both an income and expense item.

In general, the before-tax inflation premium component added to personal saving is calculated as:

$$
\text { SINFPERBT }=(\text { RINTPER }- \text { RINTPER50) APER, }
$$

where APER represents the stock of the relevant household net fixed-income assets at the beginning of the period, ${ }^{11}$ RINTPER represents the ratio of the 
Table 3: Interest Income Received and Paid, 1985

(billions of dollars)

Households

\begin{tabular}{|c|c|c|}
\hline \multicolumn{2}{|c|}{ Households } & \multirow{2}{*}{$\begin{array}{l}\text { Nonfinancial } \\
\text { Corporations }\end{array}$} \\
\hline as Persons & as Business & \\
\hline $401.1^{a}$ & $8.4^{b}$ & $105.3^{b}$ \\
\hline 82.6 & 251.5 & 219.4 \\
\hline
\end{tabular}

Interest Received

Net Paid

243.1

114.1

Less Interest Paid

as Business to Business

$150.0^{\mathrm{C}}$

Net Paid after Adjustment

93.1

114.1

Net Household

Interest Received

ancludes 91.0 billion of imputed interest from life insurance carriers and private pension plans, but not $\$ 63.9$ billion from banks, credit agencies and investment companies. These figures come from an unpublished BEA series (the interest component of Table 8.8 , line 50 ).

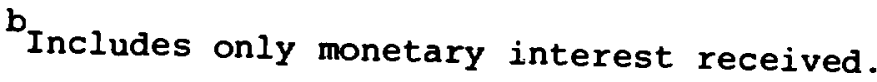

$\mathrm{C}_{\text {Includes interest on mortgages financing owner-occupied housing and capital }}$ owned and used by nonprofit organizations.

Source: NIPA, Table 8.8. 
household net interest series just discussed to APER, and RINTPER50 is the 1950 value of RINTPER. This procedure allocates any increase in interest income (adjusted for the growth in net financial assets) to our inflation component measure. It is likely that the inflation premium component in 1950, if any, was extremely small. To the extent that this component was nonzero, our measure differs from the true component by a small constant.

To obtain the after-tax inflation premium, SINFPER, we divide the inflation premium into its taxable and nontaxable components and multiply the former by (1-TXINT), where TXINT is the assumed tax rate on interest income. ${ }^{12}$ The nontaxable portion is associated with the interest income from life insurance and private pension fund reserves and net holdings of state and local government bonds. The after-tax inflation premium is the sum of the nontaxable portion and the after-tax taxable portion.

The above equation implicitly assumes that the real interest rate built into interest income was constant during the $1950-85$ period. $^{13}$ Because an increase in the real interest rate in the early 1980 s is well documented (Clarida and Friedman 1983 and Hendershott 1986), we have constructed an inflation premium with a special adjustment for the early 1980s, SINFPER80. This premium allows for the gradual adjustment of interest income to a three percentage point increase in real interest rates in 1981 . Based on an examination of the difference between RINTPER and the Livingston expected inflation data for the 1978-85 period, the SINFPER80 calculation assumes that the real interest rate incorporated in interest income was one percentage point higher in 1981, two points higher in 1982 and three points higher during 198385. This is equivalent to adding one, two, and three percentage points to the value of RINTPER50 for 1981, 1982 and 1983-85, respectively. 
The after-tax inflation premium component netted from corporate saving is calculated directly as

$$
\text { SINFCOR }=(1-\text { TXCOR })(\text { RINTCOR }- \text { RINTCOR50) ACOR, }
$$

where TXCOR is the maximum corporate tax rate and the other variables are defined analogously to those used in the personal inflation premium adjustment except that they refer to net interest paid by nonfinancial corporations on their stock of net debt. ${ }^{14}$ SINFCOR80 is SINFCOR calculated with the same adjustment to RINTCOR50 made to RINTPER50 in the calculation of SINFPER80.

Figure 2 contains graphs of SINFPER, SINFCOR, SINFPER80 and SINFCOR80, again in 1982 dollars. The upward surge in the series, owing to both rising inflation (interest rates) and growing real net stocks of financial assets (households) and liabilities (corporations), is clear. The series rise from under a billion to peaks of $\$ 127$ billion $(\$ 95$ billion with the real rate adjustment) for persons and $\$ 38$ billion ( $\$ 33$ billion) for corporations. In general, the business premium is 25 to 35 percent of the household premium. An exception is the 1969-75 period, where the business premium averaged nearly 45 percent of the household premium. Prior to the late 1970s when deregulation of many deposit rates and the growth of money market funds made household interest income responsive to interest rate changes, the business premium rose relative to the household premium when interest rates increased and fell when interest rates decreased. The relatively high business premium in the 1969-75 period reflected much higher interest rates relative to the 1960 s.

\section{Official and Adjusted Saving Rates}

Our adjusted personal saving series incorporates the five adjustments to SNIA described above. The first four adjustments are added to SNIA, while the inflation component is subtracted. Adjusted personal saving is thus: 
SADJPER = SNIAPER + SCDUR + SGPEN + SSSEC8O + STAX - SINFPER8O.

To obtain an adjusted personal saving rate, we divide the adjusted series by adjusted disposable income (and multiply by 100). The adjustments to disposable income are those indicated in the income and net-interest-paid columns of Table 2 and the tax timing adjustment. The adjusted income series is calculated as:

$$
\text { YDADJ = YDNIA + STAX + SGPEN + SSSEC80 - YINF80, }
$$

where YDNIA is NIPA personal disposable income, and YINF80 is the inflation premium adjustment for disposable income. The latter is computed from a relationship similar to equation (2), but with the interest income (adjusted for the rise in real rates in the 1980s) and net asset stock series redefined appropriately. The interest income series is increased by including imputed interest paid on personal demand deposits by financial institutions and by not excluding interest paid to business; the net asset stock is increased by the demand deposits and home mortgage and other debt of households. In terms of Table 3 , we add the $\$ 63.9$ billion of imputed interest paid to households by banks, credit agencies and investment companies and both the $\$ 150.0$ billion of mortgage interest and the $\$ 82.6$ billion of other interest paid to business by households to our 1985 total of $\$ 225.4$ billion, arriving at an adjusted total of $\$ 521.9$ billion.

Our adjusted corporate saving series includes only the inflation premium adjustment:

$$
\text { SADJCOR = SNIACOR + SINFCOR80, }
$$


where SNIACOR already incorporates the NIPA capital consumption and inventory valuation adjustments. Owing to the inflation premium adjustment, the ratio of adjusted corporate saving to adjusted official disposable income is 12 percent greater, on average, than the ratio of official corporate saving to official disposable income. However, the standard deviation of the adjusted ratio is 20 percent less. Our adjusted private saving series is the sum of the adjusted personal and corporate rates:

SADJPRI = SADJPER + SADJCOR.

Figures 3 and 4 present the adjusted and official personal and private saving rates, respectively. The most obvious difference in the adjusted and official series is their average values. Given our additions to official saving, the adjusted personal series is $6 \frac{1}{2}$ percentage points greater than the official, on average, while the adjusted private rate is 7 percentage points greater. Moreover, the differences between the adjusted and official series are far larger since 1970 than in the 1950s and early 1960s. The trend increase in the differences is the result of trends in our adjustments. The retirement contributions (government employees pension and social security) correction has a strong upward trend, adding 2 percentage points to saving rates in the early 1950 s but 7 percentage points in the 1980s. The inflation premium correction also has an upward trend, rising from zero to over 4 percentage points (for personal saving) in the early 1980s, before tailing off. No trends exist in the durables and tax timing adjustments.

The retirement correction and the difference between it and the inflation premium corrections for personal and private saving, respectively, are plotted in Figure 5. As can be seen, the difference (the net adjustment to 
saving) raises the official personal and private saving rates from 2 percentage points in 1951 to over 4 (to 5 for private saving) in the middle 1970s, after which the sum is roughly constant (with a temporary dip in the early 1980s). The adjusted personal saving rate is more volatile than the official rate; its standard deviation is nearly 70 percent greater. Moreover, the adjusted rate contains some broad movements that are not evident in the official rate. In particular, the adjusted saving rate declines from above 14 percent in 1950-51 to about 11 percent in 1958-61 and then rises back to 15 percent in 1966. During the same time span, the official rate moves erratically within a one and three-quarters percentage point band. The two series also move differently since 1978. The adjusted series declines from 15 percent to below $12 \frac{1}{2}$ percent in $1980-82$ and then rises slightly in 1984-85. In contrast, the official rate is nearly constant at about 7 percent throughout the 1978-82 period and then drops to $5 \frac{1}{2}$ percent in 1983-85. That is, the adjusted series is three-quarters of a percentage point higher in 1983-85 than in 1980-82, rather than $1 \frac{1}{2}$ percentage points lower.

Figure 6 presents the national and government (federal, state and local) saving rates, both adjusted and unadjusted, as percentages of net national product. The area between the two pairs of national and government saving rate lines represents private saving. Less than half of our adjustment to private saving represents a net addition to national saving. For the 1950-85 period, the private saving rate (as a percentage of net national product) is increased by 5.6 percentage points; the national saving rate is increased by only 2.5 percentage points (due to the consumer durables adjustment). The remaining increase to private saving comes from a 3.1 percentage point reduction in the government saving rate $(2.7$ federal and 0.4 state and local). The federal government saving adjustment is composed of the tax timing adjustment, the social security adjustment, about one-quarter of the government employees 
pension adjustment (SGPEN), and a portion of the net inflation premium adjustment (SINFPER80-SINFCOR80). The federal government share of the net inflation premium adjustment oscillates from 80 percent in the 1950 s down to almost 50 percent by the early 1970 s and then back to 80 percent by 1985 . The state and local saving adjustment is composed of the remainder of the SGPEN and net inflation premium adjustments.

Table 4 contains average national, private and federal government saving rates, both official and adjusted, for the 1982-85 period and the three preceding decades: 1952-61, 1962-71, and 1972-81, each of which concluded with a recession. 15 All three official saving rates are reasonably constant for the three decades, although the federal and national saving rates were both down by about a percentage point in the 1970s. In contrast, sharp two percentage point declines occurred in both the private and federal saving rates in the 1982-85 period, giving a whopping $4 \frac{1}{2}$ point decline in the national saving rate. The adjusted saving rate series tell the same story regarding the declines from 1972-81 to 1982-85, but the context of these declines is far different. For one thing, the decline in federal saving is not a one-time abberation but the continuation of a trend. In fact, the decrease from 1972-81 to 1982-85 is less than the decrease from 1962-71 to 1972-81. On the other hand, the decline in the private saving rate reverses an upward trend so the 1982-85 rate is nearly a point above the $1952-61$ rate, rather than at an all-time low. 
Table 4: Official and Adjusted National, Private and Federal Government Saving Rates (percent of net national product)

\begin{tabular}{|c|c|c|c|c|c|c|}
\hline & \multicolumn{2}{|c|}{ National } & \multicolumn{2}{|c|}{ Private } & Federal & Government \\
\hline & Official & Adjusted & $\overline{\text { Official }}$ & Adjusted & $\overline{\text { Official }}$ & Adjusted \\
\hline $1952-61$ & 7.50 & 9.55 & 8.16 & 12.47 & -0.46 & -2.35 \\
\hline $1962-71$ & 8.48 & 11.14 & 9.05 & 14.72 & -0.66 & -3.34 \\
\hline $1972-81$ & 7.64 & 10.08 & 8.64 & 15.03 & -2.06 & -5.60 \\
\hline $1982-85$ & 3.11 & 5.38 & 6.88 & 13.30 & -4.29 & -7.55 \\
\hline
\end{tabular}




\section{Personal Saving Equation Estimates}

Estimates of equations explaining real per capita personal saving are reported in this section. The primary purpose of the equations is to provide a test, albeit crude, of our proposed personal saving adjustments. If, for example, an adjustment should have a coefficient of minus unity in an equation explaining NIPA saving and the estimated coefficient is positive, this would constitute strong grounds for rejecting our adjustment. The equations are based on a model of planned wealth accumulation that includes measures of wealth, income, capital gains, the GNP gap (all in per capita constant 1982 dollars), the real after-tax interest rate and the age composition of the population as explanatory variables (see Hendershott and Peek, 1985a, for a detailed description of the model). This section begins with a discussion of the variables and estimation procedure, reports the results, and then analyzes their implications for the relationship between personal and corporate saving.

\section{A. The Variables and Estimation Procedure}

Our disposable labor income measure is equal to the NIPA measures of wages and salaries, other labor income, and a proportion of proprietor's income, less labor's share of actual personal income tax liabilities and employee contributions for social insurance, plus the sum of government employees retirement benefits and SGPEN (equal to contributions plus accrued interest on cumulated contributions) and both SSSEC80 and OASI benefit payments (assumed to equal accrued interest on the stock of cumulated oAsI contributions). The latter additions are needed to make the income measure consistent with our adjusted saving measure. Transfer payments are set equal to NIPA transfer payments less both government employees retirement benefits and OASI benefits (which we have reallocated to disposable labor income). 
Both adjusted disposable labor income and adjusted transfer payments are divided into their expected and unexpected components through regression analysis (see Hendershott and Peek, 1985a, for specific details). The predicted value from an equation with the variable in question being regressed on a set of predetermined variables is taken as the expected component; the residual series from the regression is taken as the proxy for the unexpected component. We use annual observations for the 1951-85 period. The explanatory variables for real per capita labor income/transfer payments are four lagged values of the dependent variable and one lagged value of each of the following: real government expenditures, the difference (gap) between potential and actual real GNP, the real value of the Ml definition of the money supply, the one-year after-tax nominal treasury bill yield (RAT), an index of marginal personal income tax rates, and the one-year ahead Livingston expected inflation rate from the December survey $(\pi)$. The potential GNP measure is the middle expansion trend GNP series calculated by the Bureau of Economic Analysis. All variables except for interest, tax and inflation rates are per capita. The real net capital gains data were calculated from the Board of Governors (1986) as in Hendershott and Peek (1985b). We combined household assets and liabilities (including noncorporate business holdings) into three categories: (1) tangible capital (residential structures, consumer durable goods, land, and the plant and equipment and inventories of nonprofit institutions and noncorporate business), (2) corporate equities, held both directly and indirectly through household life insurance and pension fund reserves, and (3) all other financial assets less liabilities. The real capital gains measures were divided into their expected and unexpected components using a regression procedure similar to that used for the labor income and transfer variables. The capital gains regressions have the ratio of net capital gains to the beginning-of-period stock of assets as the dependent 
variable. The explanatory variables include four lagged values of the dependent variable, the expected inflation rate, and lagged values of the first differences of all the explanatory variables in the labor income/transfer equations. For the equities equation we also include both our adjusted corporate saving variable lagged one period divided by the beginning-of-period stock of corporate equities and the top corporate income tax rate.

Table 5 presents estimates of personal saving equations with and without our tax timing, government pension, social security, and inflation premium adjustments. The consumer durables adjustment cannot be employed as a regressor because it is an endogenous decision variable. ${ }^{16}$ According to the Life Cycle/Permanent Income Hypothesis, individuals choose their level of consumption (durable plus nondurable) subject to their budget constraint. Not only do they choose the level of their consumption, but they also choose its composition; they can substitute more or less durable services for nondurables and scrvices within their total consumption. In contrast, consumer choice over government employees pension or social security contributions and the inflation premium in interest income is severely limited, and thus these adjustments can be employed as regressors. The hypothesized minus one coefficient on the consumer durables adjustment is imposed in our estimation by adding this adjustment to NIPA saving and using this sum as the dependent variable.

Regressors considered, in addition to our saving adjustments and the income and capital gains variables previously described, include: the beginning-of-period stock of real household wealth (with financial assets and liabilities converted from par to market values) from Board of Governors (1986); the share of the population over 64 from the Council of Economic Advisers, 1987; the GNP gap; and the one-year after-tax expected real interest rate from the previous December, calculated as RAT - $\pi$. Both the population share and 
real interest rate variables (less their mean values) have been multiplied by expected adjusted disposable labor income. All of the dollar variables are per capita constant 1982 dollar magnitudes.

The rather high correlations between pairs of explanatory variables make it very difficult to pinpoint the individual effects of the variables on personal saving. For example, the pairwise correlations between wealth, expected labor income, expected transfers, share of population over 64 , SINFPER80, SGPEN and SSSEC80 are each above 0.9. Furthermore, the pairwise correlations of each of these variables with expected capital gains on net financial assets ranges between -0.76 and -0.92 . First-differencing the data substantially reduces the collinearity between pairs of explanatory variables. Consequently, each equation in Table 5 has been estimated using firstdifferenced data. To simplify the exposition and to preserve degrees of freedom, we have combined the expected and unexpected components of disposable labor income, which tended to have very similar estimated coefficients. Similarly, because the estimated coefficients on expected transfer payments, expected and unexpected capital gains on net financial assets, and unexpected capital gains on tangible assets tended to be statistically insignificant (and in many cases, quite erratic) across the various saving equation specifications, they have been omitted from the equations presented in the table. Finally, the one-year after-tax real Treasury bill rate was omitted because it never had a coefficient of either quantitative or statistical significance. ${ }^{17}$ 


\section{B. The Estimates}

Columns (1) and (2) in Table 5 are estimated with data from the full 1952-85 sample period. The first column explains personal saving (including net durables, SNIAPER + SCDUR) without our proposed adjustments. Only the coefficients on wealth, disposable labor income, population share, and expected gains on tangible assets are statistically significant at the 95 percent confidence level with the predicted sign, although the unexpected transfer payments and GNP gap variables contribute to the explanatory power of the equation. In column 2, our saving adjustments (without the 1980s modifications) are included as additional explanatory variables. Each of the estimated coefficients on the four adjustment variables, except that on SSSEC, is more than two standard errors from zero with the expected sign; that on SSSEC is more than one and a half standard errors. Moreover, none of the four estimated coefficients are more than two standard errors away from their predicted values. However, the point estimates of the coefficients on both SGPEN and SINFPER are nearly double their predicted values.

Because the equation underlying column 2 makes no special modification for either the 1980 s decline in the expected rate of return on social security relative to market interest rates or the $1980 \mathrm{~s}$ rise in real interest rates, the estimates are suspect. The problem with the 1980 s observations can be solved either by eliminating the troublesome 1981-85 observations from the estimation period (column 3 ) or by retaining the entire sample period but using the modified measures of the social security (SSSEC80) and inflation premium (SINFPER80) adjustments (Column 4). For the 1952-80 subperiod, each of the estimated coefficients on the saving adjustments is within a standard error of its predicted value with the exception of that on STAX which is just slightly more than a single standard error away. All but the inflation premium coefficient differ significantly from zero. Alternatively, when SSSEC80 and 
Table 5

Personal Saving (Including Net Investment in Consumer Durables Regressions, Annual Observations for 1952-85

(First Differences of Real Per Capita Data, Standard Errors in Parentheses)

\begin{tabular}{|c|c|c|c|c|c|c|c|}
\hline Explanatory Variables & (I) & $(2)^{a}$ & $(3)^{b}$ & (4) & (5) & (6) & (7) \\
\hline $\begin{array}{l}\text { Tax Timing } \\
\text { Adjustment }\end{array}$ & - & $\begin{array}{r}-1.128 \\
1.230\end{array}$ & $\begin{array}{r}-1.289 \\
(.258)\end{array}$ & $\begin{array}{r}-1.044 \\
(.233)\end{array}$ & $\begin{array}{r}-1.051 \\
(.233)\end{array}$ & -1.00 & -1.00 \\
\hline $\begin{array}{l}\text { Government Pension } \\
\text { Adjustment }\end{array}$ & - & $\begin{array}{r}-1.837 \\
(.707)\end{array}$ & $\begin{array}{r}-1.663 \\
(.729)\end{array}$ & $\begin{array}{l}-1.501 \\
(.657)\end{array}$ & $\begin{array}{r}-1.779 \\
(.614)\end{array}$ & -1.00 & -1.00 \\
\hline $\begin{array}{l}\text { Social Security } \\
\text { Adjustment }\end{array}$ & - & $\begin{array}{l}-.922 \\
(.547)\end{array}$ & $\begin{array}{r}-1.443 \\
(.603)\end{array}$ & $\begin{array}{r}-1.358 \\
(.497)\end{array}$ & $\begin{array}{r}-1.476 \\
(.487)\end{array}$ & -1.00 & -1.00 \\
\hline $\begin{array}{l}\text { Inflation Premium } \\
\text { Adjustment }\end{array}$ & - & $\begin{array}{l}1.871 \\
(.619)\end{array}$ & $\begin{array}{l}.826 \\
(.841)\end{array}$ & $\begin{array}{l}.980 \\
(.361)\end{array}$ & $\begin{array}{l}.956 \\
(.360)\end{array}$ & 1.00 & 1.00 \\
\hline Wealth & $\begin{array}{l}-.0309 \\
(.0152)\end{array}$ & $\begin{array}{l}-.0439 \\
(.0123)\end{array}$ & $\begin{array}{l}-.0307 \\
(.0133)\end{array}$ & $\begin{array}{l}-.0360 \\
(.0111)\end{array}$ & $\begin{array}{l}-.0399 \\
(.0106)\end{array}$ & $\begin{array}{l}-.0415 \\
(.0094)\end{array}$ & $\begin{array}{l}-.0395 \\
(.0091)\end{array}$ \\
\hline Labor Income & $\begin{array}{l}.497 \\
(.087)\end{array}$ & $\begin{array}{l}.648 \\
(.084)\end{array}$ & $\begin{array}{l}.608 \\
(.085)\end{array}$ & $\begin{array}{l}.584 \\
(.066)\end{array}$ & $\begin{array}{l}.567 \\
(.065)\end{array}$ & $\begin{array}{l}.523 \\
(.052)\end{array}$ & $\begin{array}{l}.509 \\
(.051)\end{array}$ \\
\hline $\begin{array}{l}\text { Unexpected } \\
\text { Transfers }\end{array}$ & $\begin{array}{l}-.783 \\
(.505)\end{array}$ & $\begin{array}{l}.198 \\
(.391)\end{array}$ & $\begin{array}{c}.682 \\
(.419)\end{array}$ & $\begin{array}{l}.299 \\
(.396)\end{array}$ & $\begin{array}{l}.264 \\
(.395)\end{array}$ & $\begin{array}{l}.122 \\
(.325)\end{array}$ & $\begin{array}{l}.150 \\
(.313)\end{array}$ \\
\hline $\begin{array}{l}\text { Percent Popula- } \\
\text { tion over Age } 64\end{array}$ & $\begin{array}{l}-3.60 \\
(1.68)\end{array}$ & $\begin{array}{l}-5.21 \\
(1.49)\end{array}$ & $\begin{array}{l}-3.63 \\
(1.79)\end{array}$ & $\begin{array}{l}-3.01 \\
(1.26)\end{array}$ & -1.50 & -1.50 & -1.50 \\
\hline GNP gap & $\begin{array}{l}.0693 \\
(.0488)\end{array}$ & $\begin{array}{l}.0564 \\
(.0342)\end{array}$ & $\begin{array}{l}.0455 \\
(.0424)\end{array}$ & $\begin{array}{l}.0892 \\
(.0357)\end{array}$ & $\begin{array}{l}.0876 \\
(.0356)\end{array}$ & $\begin{array}{l}.0785 \\
(.0315)\end{array}$ & $\begin{array}{l}.1006 \\
(.0327)\end{array}$ \\
\hline $\begin{array}{l}\text { Expected Gains } \\
\text { on Tangible Assets }\end{array}$ & $\begin{array}{l}-.0657 \\
(.0257)\end{array}$ & $\begin{array}{l}-.0124 \\
(.0228)\end{array}$ & $\begin{array}{l}-.0302 \\
(.0310)\end{array}$ & $\begin{array}{l}-.0382 \\
(.0190)\end{array}$ & $\begin{array}{l}-.0377 \\
(.0190)\end{array}$ & $\begin{array}{l}-.0358 \\
(.0167)\end{array}$ & $\begin{array}{l}-.0467 \\
(.0171)\end{array}$ \\
\hline $\begin{array}{l}\text { Expected Gains on } \\
\text { Corp. Equities }\end{array}$ & $\begin{array}{l}-.0058 \\
(.0137)\end{array}$ & $\begin{array}{l}-.0245 \\
(.0111)\end{array}$ & $\begin{array}{l}-.0226 \\
(.0110)\end{array}$ & $\begin{array}{l}-.0252 \\
(.0104)\end{array}$ & $\begin{array}{l}-.0297 \\
(.0097)\end{array}$ & $\begin{array}{l}-.0277 \\
(.0084)\end{array}$ & $\begin{array}{l}-.0317 \\
(.0084)\end{array}$ \\
\hline $\begin{array}{l}\text { Unexpected Gains } \\
\text { on Corp. Equities }\end{array}$ & $\begin{array}{l}.0013 \\
(.0131)\end{array}$ & $\begin{array}{l}-.0121 \\
(.0094)\end{array}$ & $\begin{array}{l}-.0178 \\
(.0097)\end{array}$ & $\begin{array}{l}-.0158 \\
(.0095)\end{array}$ & $\begin{array}{l}-.0166 \\
(.0094)\end{array}$ & $\begin{array}{l}-.0164 \\
(.0085)\end{array}$ & $\begin{array}{l}-.0145 \\
(.0082)\end{array}$ \\
\hline Minutes to Midnight & - & - & - & - & - & - & $\begin{array}{l}.00140 \\
(.00076)\end{array}$ \\
\hline $\begin{array}{l}\text { SEE } \\
\text { DW }\end{array}$ & $\begin{array}{r}.632 \\
63.87 \\
2.31\end{array}$ & $\begin{array}{r}.854 \\
43.72 \\
2.15\end{array}$ & $\begin{array}{r}.863 \\
41.73 \\
2.04\end{array}$ & $\begin{array}{r}.856 \\
43.46\end{array}$ & $\begin{array}{r}.848 \\
43.46\end{array}$ & $\begin{array}{r}.817 \\
41.56\end{array}$ & $\begin{array}{r}.837 \\
40.06\end{array}$ \\
\hline DW & 2.31 & 2.15 & 2.04 & 1.78 & 1.79 & 1.96 & 2.14 \\
\hline
\end{tabular}

a The social-security and inflation-premium adjustments for the column do not include the 1980 s corrections.

b

These estimates are for the 1952-80 period. 
SINFPER80 are used as regressors and the equation is estimated over the entire 1952-85 sample period, each of the four coefficients differs significantly from zero and each of the four is well within a single standard error of its predicted value. All of the estimated coefficients except for those on unexpected transfer payments and unexpected gains on corporate equities are now statistically significant with the expected sign. The introduction of the saving adjustments reduces the standard error of the equation by over 30 percent compared to column 1. Whether we omit the 1981-85 observations or modify the social security and inflation premium adjustments, we obtain very similar results. The sharpest differences between the two equations are the doubling of the GNP gap coefficient and the sharp decline in both the unexpected transfer payments coefficient and the standard error of the inflation premium adjustment coefficient as we move from column 3 to column 4 .

The only problem with the estimates in column 4, in our view, is the magnitude of the population share coefficient. This coefficient implies too large a negative impact of the aging of the population. In fact, a coefficient of -1.5 is as large, in absolute value, as seems plausible (Hendershott and Peek, 1985a, p. 89). Constraining the coefficient to this value (column 5) makes little difference. The equation standard error is virtually unchanged, and none of the individual coefficients changes by as much as half a standard deviation. The pension adjustment coefficient is now slightly more than a standard error from its expected value. ${ }^{18}$

Column 6 contains estimates with the coefficients on all the saving adjustments constrained to their theoretical values. These estimates imply significant positive labor income (coefficient of 0.52) and GNP gap (0.78) responses, and significant negative wealth $(-0.042)$, expected gains on tangible 
assets $(-0.036)$, and expected $(-0.028)$ and unexpected $(-0.016)$ corporate equity gains relationships. The unexpected transfer payments coefficient, in contrast, is less than half a standard error from zero.

The final equation in Table 5 includes Slemrod's (1986) minutes to midnight nuclear-fear variable. Increased fear of nuclear holocaust would likely reduce the propensity to save. When this variable (scaled by expected disposable labor income) is added to our basic equation, the estimated coefficient is significantly greater than zero $(t$-statistic $=1.84) .^{19}$ of the other estimated coefficients, only those on the GNP gap and expected gains on tangible assets change (barely) by as much as half a standard error. 20

How do the various explanatory variables interact to explain the broad swings in the adjusted personal saving rate discussed earlier, namely the rise from an average $12 \frac{8}{6}$ rate in the $1954-64$ period to $15 \frac{1}{2} \%$ in the $1966-78$ period and then the decline to $12 \frac{1}{2} \%$ in the 1980s? The two upper series plotted in Figure 7 are the adjusted personal saving rate and the wealth/income ratio. The negative correlation between the series is obvious. The lower series is an average of the rate of growth in our real adjusted disposable income series for the current and preceding two years. This average correlates positively with the saving rate and negatively with the wealth ratio, although the correlations break down somewhat in the 1969-78 decade. The correlations with the saving and wealth ratios indicate the two channels through which real income growth affects saving: more rapid growth raises the saving rate directly, because the marginal propensity to save exceeds the average, and indirectly, because the saving rate is negatively related to the wealth-income ratio which falls when income grows more rapidly than wealth. The last relevant part of the explanation concerns movements in the stock market. Stock market gains averaged (as a share of income) $9.28,-2.98$ and 6.08 in the 1954-66, 1968-78 and 1980-85 periods. These gains alter the wealth-income ratio (the negative 
gains in the middle period explain the break down in the negative relationship between income growth and the wealth ratio) and also have a small direct impact on the saving rate.

c. The Corporate Veil and Denison's Law

A question often asked is: do households directly alter their saving in response to changes in corporate saving (Feldstein 1973)? The answer usually given is yes, to a significant extent (Howrey and Hymans 1978 and von Furstenberg 1981). That is, the coefficient on corporate saving when it is added to a personal saving equation generally lies between -0.45 and -0.7 and is statistically different from zero. If we regress official NIPA saving on the variables in column 1 plus official NIPA corporate saving, we get a similar result (coefficient of -0.44 with standard error of 0.23 ). However, this estimate comes from an equation in which both personal and corporate saving are mismeasured. More importantly, the measurement errors are negatively correlated; personal saving is too high during inflationary periods and corporate saving is too low. When the series are corrected, i.e., personal saving is lowered by the household inflation premium adjustment (and augmented by the other adjustments) and corporate saving is raised by the corporate inflation premium adjustment, the coefficient on corporate saving is positive $(0.21$ with a standard error of 0.13$)$.

Even earlier, Denison (1958) focused attention on the relative stability of the gross private saving rate. He argued that, for many purposes, analysis of the total private saving rate is more appropriate than considering the personal and corporate saving components separately. He stated: "Indeed, it was the clear tendency, readily observable even in the dollar figures, for personal saving and corporate saving to move in offsetting fashion that first led me to deal directly with total saving (p. 264)." Later work by David and Scadding (1974) and others confirmed this relationship. When official gross 
saving rates are plotted for the $1952-85$ period, the negative correlation between them is, indeed, "readily observable"; moreover, the simple correlation coefficient is -0.31 . However, such a relationship is not observable between the adjusted saving rates, and their simple correlation coefficient is 0.25 . Thus, the often noted negative correlation between the personal and corporate saving rates, either gross or net, appears to be due to the negatively correlated inflation premia inappropriately contained in the official saving measures.

The absence of a negative relation between household and business saving, correctly measured, does not mean that households do not respond rationally to corporate real wealth accumulation. If corporations were to generate an additional dollar of retained earnings through wise investments, the market value of corporate equity would rise. If the higher retained earnings were not expected to continue, then the equity value would increase by $\$ 1$ and households, by our estimates, would consume 1.5 cents (the coefficient on unexpected corporate equity gains) in the current year and 4.0 cents (the wealth coefficient) in subsequent years. If retained earnings were expected to be higher in perpetuity, then the market value of corporate equity would rise by a multiple, say $\$ 25$, and households would consume 36 cents of the initial $\$ 1$ $(0.015$ times $\$ 25)$ and $\$ 1.00(0.040$ times $\$ 25)$ in each of the subsequent years.

\section{Summary and Conclusion}

Personal and private saving rates have hit post-1950 lows in the 1980s according to official saving statistics. The average personal saving rate for 1983-85 was 5.6 percent, less than any year in the 1950-82 period and 20 percent below the average rate for that period. The average private saving rate for 1982-85 was 8.6 percent, less than any year in the 1950-81 period and 23 percent below the average rate for that period. 
But the official statistics contain a number of conceptual measurement errors. The major ones are: (1) treating net investment in consumer durables as consumption, (2) effectively treating net investment in government retirement plans, especially social security, as taxes, and (3) counting as interest income that part of interest received which is both due to inflation and available to compensate for inflation's erosion of fixed-valued asset stocks. The first two errors cause the official personal and private saving rates to understate the true rates; the last causes an overstatement of both rates, although less for private saving because the private sector is a smaller net creditor than is the personal sector.

The consumer durables correction is highly cyclical and generally raises saving rates by between $1 \frac{1}{2}$ and $4 \frac{1}{2}$ percentage points over the 1950-85 period. The retirement contributions correction, in contrast, has a strong upward trend, adding 2 percentage points to saving rates in the early 1950s but 7 percentage points in the 1980s. The inflation premium correction also has an upward trend, rising from zero to $4 \frac{1}{4}$ percentage points (for personal saving) in the early 1980s, before tailing off. The difference between these trend adjustments raises the official personal and private saving rates by increasing amounts between 1951 and the middle 1970s.

Because of this trend in our adjustments, our adjusted saving rates in the middle 1980 s are generally higher than the rates during the 1950-65 period and only slightly below the averages for the entire 1950-85 period. For adjusted personal saving, the rate for each year so far in the 1980 s exceeds every year in the 1958-63 period, and the adjusted rate for 1984-85 exceeds the rate in every year in the 1954-64 span. Moreover, the 1984-85 rate is only a half percentage point below the $1950-83$ average, in contrast to the $1 \frac{1}{2}$ 
percentage points the official rate is below its 1950-83 average. The adjusted personal saving rate was low in 1954-64, high in 1966-78 and then slightly below average in 1980-85.

Basically, the same description holds for the adjusted private saving rate which so far in the 1980s is slightly below the 1950-85 average, but above its value during most of the 1950s and early 1960s. More specifically, the 1984-85 rate exceeds the rate in every year between 1952 and 1963, except 1955. Further, the adjusted private saving rate in 1984-85 is only a quarter percentage point below the 1950-83 average, in contrast to the two percentage point difference in the official private saving rate in these periods. The adjusted private saving rate was low in 1952-63, high in 1964-79 and only slightly below average so far in the 1980 s.

In contrast to personal saving, corporate saving has been less volatile than the official statistics indicate. The official rate has been especially low during high inflation periods $(1974-75,1980-82)$. When the inflationpremium correction is added (some of corporate interest expense is simply compensation for declines in the real value of their debt), these low values are smoothed out. The inflation-premium corrections, for both corporate and personal saving, have another interesting effect: they remove the negative correlation between personal and corporate saving. For the 1950-85 period, the official personal and corporate saving rates, where disposable personal income is the denominator, exhibit a correlation of -0.23 ; the adjusted saving rates, where adjusted disposable income is the denominator, have a correlation coefficient of 0.22 . That is, earlier evidence on households "seeing through the corporate veil" reflected measurement errors in the two series (the negatively correlated inflation-premia). Households respond rationally to corporate retentions that raise stock prices and thus wealth; they do not irrationally respond to retentions that are not viewed as increasing wealth. 
To summarize, private saving has been relatively robust in recent years, according to our adjusted saving series. While the rate is below peak rates in the 1970s, it is close to the average rate for the 1950-82 period. On the other hand, the decrease in federal government saving in the 1982-85 period, rather than being a one-time aberration, is simply the continuation of a trend starting in the 1960 s. 


\section{Footnotes}

1. See, for example, the studies by Auerbach, Kane, and Jianakoplos in Hendershott (1985).

2. As straight-forward as this definition is, conceptual and practical difficulties exist in the determination of what constitutes an increase in real resources, not the least of which is measuring changes in unfunded pension wealth (private and social security), a task requiring heroic assumptions about future legislation, tax treatment and discount rates. See, for example, the studies by Auerbach and Hendershott and Peek (Chap. 3) in Hendershott (1985b).

3. See Hendershott and Peek (1985a).

4. Rather than being retained, capital was withdrawn from these enterprises at an annual rate of $\$ 64$ billion over the $1982-85$ period.

5. For a fascinating analysis of the illogic of government accounting methods, including those for social security, see Kotlikoff (1986).

6. We also considered an accelerated-depreciation adjustment for business saving. When capital purchases are written off faster than capital productivity erodes, taxes on current profits are postponed. In effect, businesses are borrowing interest free to reduce current taxes, and thus saving is overstated. The overstatement of saving is the implicit amount firms are borrowing in order to be able to pay the extra taxes that will come due when economic depreciation on today's investment eventually exceeds tax depreciation. However, the extra taxes only come due to the extent that the business shrinks or depreciation allowances are made less generous in the future. For an ongoing concern that does not expect a shortening of tax lives, the implicit amount borrowed is zero; the deferral is a permanent gift. 
7. To be complete, we should also impute income from the use of durables to consumption. However, the same imputation would be made to personal income, leaving saving unaffected.

8. Blades and Sturm (1982) claim to have made this adjustment, but we do not know how accrued interest (either the rate of return on social security or the stock of accumulated contributions to which it is applied) could be calculated.

9. See Park (1986) and articles cited therein for a more detailed discussion of the tax liabilities series.

10. The inflation adjustment was first addressed by Poole (1972). His measure of the inflation premium in disposable income was constructed as:

$$
\text { YPREM }=\frac{\pi}{R C B} \text { YINT, }
$$

where $\pi, R C B$, and YINT represent the anticipated inflation rate, the corporate bond rate, and net interest income.

11. In terms of Table 1 , this stock equals the integrated household holdings (column 3) of other deposits and credit market assets plus life insurance and pension fund holdings of the same assets (which are implicit in household insurance and pension reserves) minus other debt, all at market values.

12. The TXINT series is constructed from data contained in annual issues of the U.S. Internal Revenue Service's Statistics of Income, Individual Income Tax Returns. Following wright (1969), the tax rate is calculated as a weighted average of the marginal personal income tax rate for each adjusted gross income class. The weight for each class is equal to its share of the total interest received by all income classes. 
13. This is not meant to suggest that we think the real interest rate was constant; ample empirical evidence exists that the real rate has varied cyclically (Hendershott and Huang 1985, for example). However, during the 1950-80 period this variation has been on the order of only two percentage points. Moreover, the variation in the rate built into interest income is substantially less given the lags with which this income reflects rate movements. In contrast, interest income incorporates a major (six to eight percentage point) trend increase in expected inflation between 1950 and 1980 .

14. In terms of Table 1 , this stock equals nonfinancial corporate (column 4) other debt less other deposits and credit market instruments, all at market values. The after-tax premium can be calculated directly because nontaxable interest income of corporations is negligible.

15. Because this study is primarily concerned with private saving, the adjustment to federal government saving is incomplete, e.g., government net investment in tangible capital should be included as net investment in consumer durables is included in household saving. We have made only these adjustments to government saving that are required by our adjustments to private saving.

16. We thank Edward McKelvey for emphasizing the general problem of bias in the estimated coefficients on the adjustment variables. Technically, bias will exist if a variable is correlated with the error term. As noted in the text, this is likely to be true for the consumer durables adjustment but not for the other adjustments.

17. While the real after-tax interest rate has a negligible direct impact on personal saving, this rate has a major indirect impact through capital gains on tangible wealth (Hendershott and Peek, 1985a). 
18. The Federal Reserve series exhibits surprising volatility lespecially troubling is a $\$ 4 \frac{1}{2}$ billion decline in the state and local component in 1979 followed by a $\$ 10$ billion increase in 1980). Holloway (1987) presents an alternative series excluding military federal employees. When we use his series for state and local employees and the Federal Reserve's federal employee's series (about one-quarter of the total), the estimated coefficient and its standard error both rise by nearly 50 percent. The pension coefficient is still more than two standard deviations from zero and less than two standard deviations from minus unity.

19. The coefficient and its level of significance are much higher when minutes to midnight is included in an equation explaining official NIPA personal saving without the saving adjustments. When combined with the regressors included in column 1 , the coefficient is 0.0049 with a t-statistic of four.

20. Because corporate equities account for such a large proportion of the movement in total household wealth, we reestimated our final equation with wealth separated into two components: corporate equities and noncorporateequity wealth. The noncorporate equity component has the larger impact $(-.0477$ versus -.0333$)$, but the coefficients are not statistically different (their standard errors are about 0.012 ). 
References

Auerbach, Alan J. 1982. "Issues in the Measurement and Encouragement of Business Saving." In Saving and Government Policy, Conference Series No. 25, Boston Mass.: Federal Reserve Bank of Boston, pp. 79-99. Auerbach, Alan J. and Lawrence J. Kotlikoff. 1986. "An Evaluation of Empirical Tests of Social Security and Savings." In Social Policy Evaluation: An Economic Perspective, edited by E. Helpman et.al., pp. 161-81. New York: Academic Press.

Blades, Derek W. and Peter H. Sturm. 1982. "The Concept and Measurement of Savings: The United States and Other Industrialized Countries." In Saving and Government Policy, Conference Series No. 25, Boston, Mass.: Federal Reserve Bank of Boston, pp. 1-30.

Board of Governors of the Federal Reserve System. 1986. Balance Sheets for the U.S. Economy 1946-85. Washington, D.C.: U.S. Government Printing office.

Clarida, R.H. and Benjamin M. Friedman. 1983. "The Behavior of U.S. Shortterm Interest Rates Since October 1979." Journal of Finance 39 (July), 671-82.

Council of Economic Advisors. 1987. Economic Report of the President. Washington, D.C.: U.S. Government Printing office.

David, Paul A. and John L. Scadding. 1974. "Private Savings:

Ultrarationality, Aggregation, and "Denison's Law." Journal of Political Economy 82 (March/April): 225-249.

Denison, Edward. 1958. "A Note on Private Saving." Review of Economics and Statistics 15 (August): 261-267.

Eisner, Robert, and Paul J. Pieper. 1984. "A New View of the Federal Debt and Budget Deficits." American Economic Review 74 (March) : 11-29. 
Evans, Owen. 1983. "Social Security and Household Saving in the United States." IMF Staff Papers 30 (September) : 601-618.

Feldstein, Martin. 1973. "Tax Incentives, Corporate Saving, and Capital Accumulation in the United States." Journal of Public Economics 2 (February): 159-171.

Hendershott, Patric H. 1985. Editor, The Level and Composition of Household Saving, Ballinger Publishing Company, Cambridge, Mass.

Hendershott, Patric H. 1986. "Debt and Equity Returns Revisited." In Financing Corporate Capital Formation, edited by Benjamin Friedman, pp. 35-50. Chicago: University of Chicago Press.

Hendershott, Patric H. and Roger Huang. 1985. "Debt and Equity Yields: 1926-80." In Corporate Capital Structure in the United States, edited by Benjamin Friedman, pp. 17-63. Chicago: University of Chicago Press. Hendershott, Patric H. and Joe Peek. 1985a. "Household Saving: an Econometric Investigation." In Hendershott, ed. 1985, pp. 63-100.

Hendershott, Patric H. and Joe Peek, 1985b. "Real Household Capital Gains and Wealth Accumulation." In Hendershott, ed., 1985, pp. 41-61.

Holloway, Thomas M. 1987. "Present NIPA Saving Statistics: Their Characteristics and Limitations." This volume.

Howrey, E. Phillips and Saul H. Hymans. 1978. "The Measurement and Determination of Loanable-Funds Saving." Brookings Papers on Economic Activity (3): 655-85.

Jump, Gregory V. 1980. "Interest Rates, Inflation Expectations, and Spurious Elements in Measured Real Income and Saving." American Economic Review 70 (December): 990-1004.

Kotlikoff, Laurence J. 1986. "Deficit Delusion." The Public Interest 84 (Summer): 53-65. 
McSteen, Martha A. 1985. "Fifty Years of Social Security." Social Security Bulletin 48 (August): $36-44$.

Munnell, Alicia. 1977. The Future of Social Security, The Brookings Institution, Washington D.C.

Park, Thae S. 1986. "Federal Personal Income Taxes: Revised and Updated Estimates of Liabilities and Payments, 1949-84," Survey of Current Business (May): 40-41.

Peek, Joe. 1982. "Personal Saving and the Measurement of Income Tax Liabilities." Review of Economics and Statistics 64 (February): 143-47. Poole, William. 1972. "The Role of Interest Rates and Inflation in the Consumption Function." Brookings Papers on Economic Activity (no. 1): $211-20$.

Slemrod, Joel. 1986. "Saving and the Fear of Nuclear War." Journal of Conflict Resolution 30 (no 3): 403-19.

U.S. Bureau of Economic Analysis. 1981. The National Income and Product Accounts of the United States, 1929-76. Washington, D.C.: U.S. Government Printing office.

U.S. Department of Health and Human Services. 1986. Social Security Bulletin - An Annual Statistical Supplement, Washington D.C.: U.S. Government Printing office.

U.S. Internal Revenue Service. Statistics of Income, Individual Income Tax Returns. Washington, D.C.: U.S. Government Printing office. von Furstenberg, George M. 1981. "Saving." In How Taxes Affect Economic Behavior, edited by Henry Aaron and Joseph Pechman, pp. 327-490. Washington, D.C.: The Brookings Institution. Wright, Colin. 1969. "Saving and the Rate of Interest." In The Taxation of Income from Capital, edited by Arnold C. Harberger and Martin J. Bailey PP. 275-300. Washington D.C.: The Brookings Institution. 


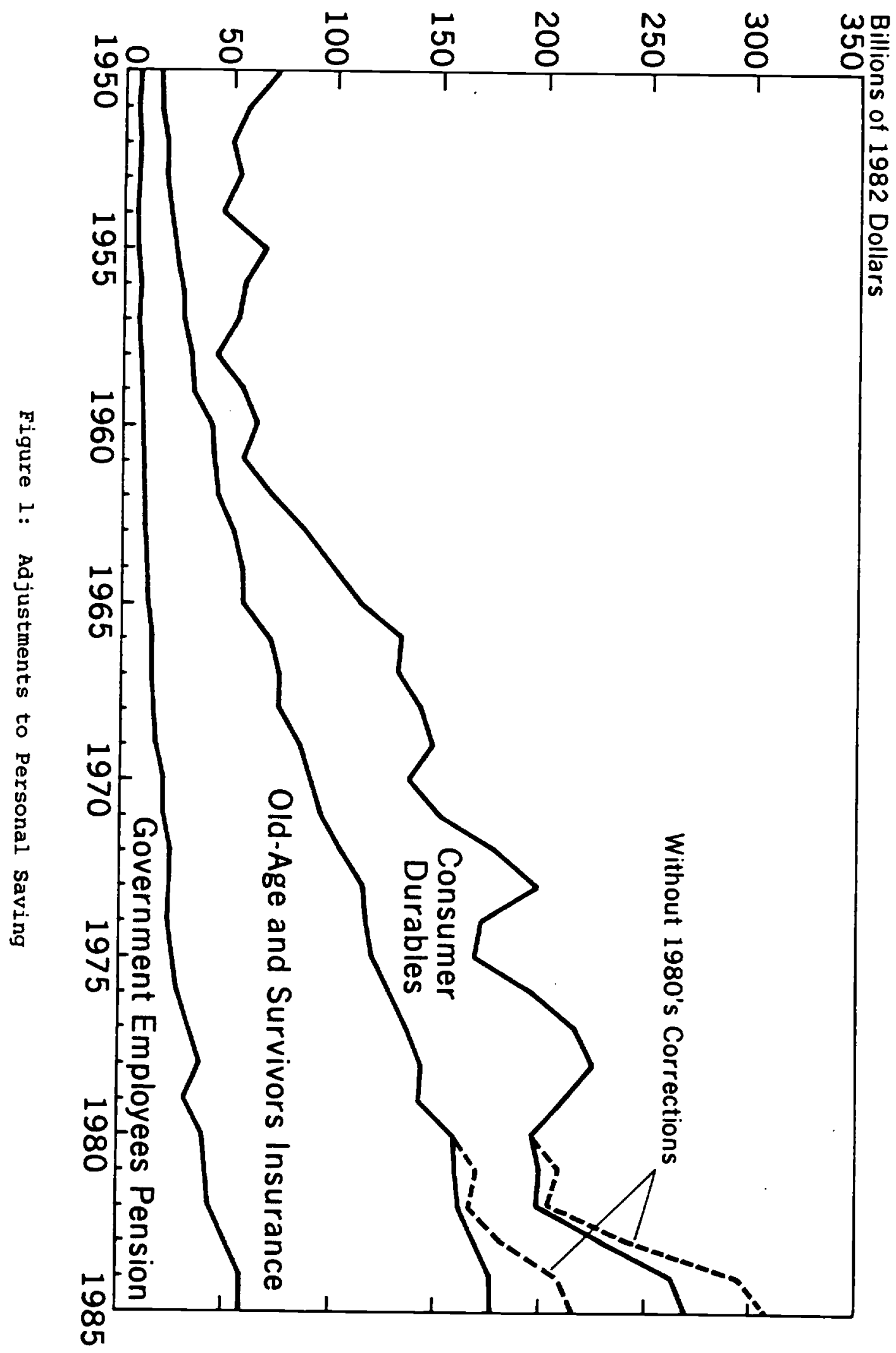




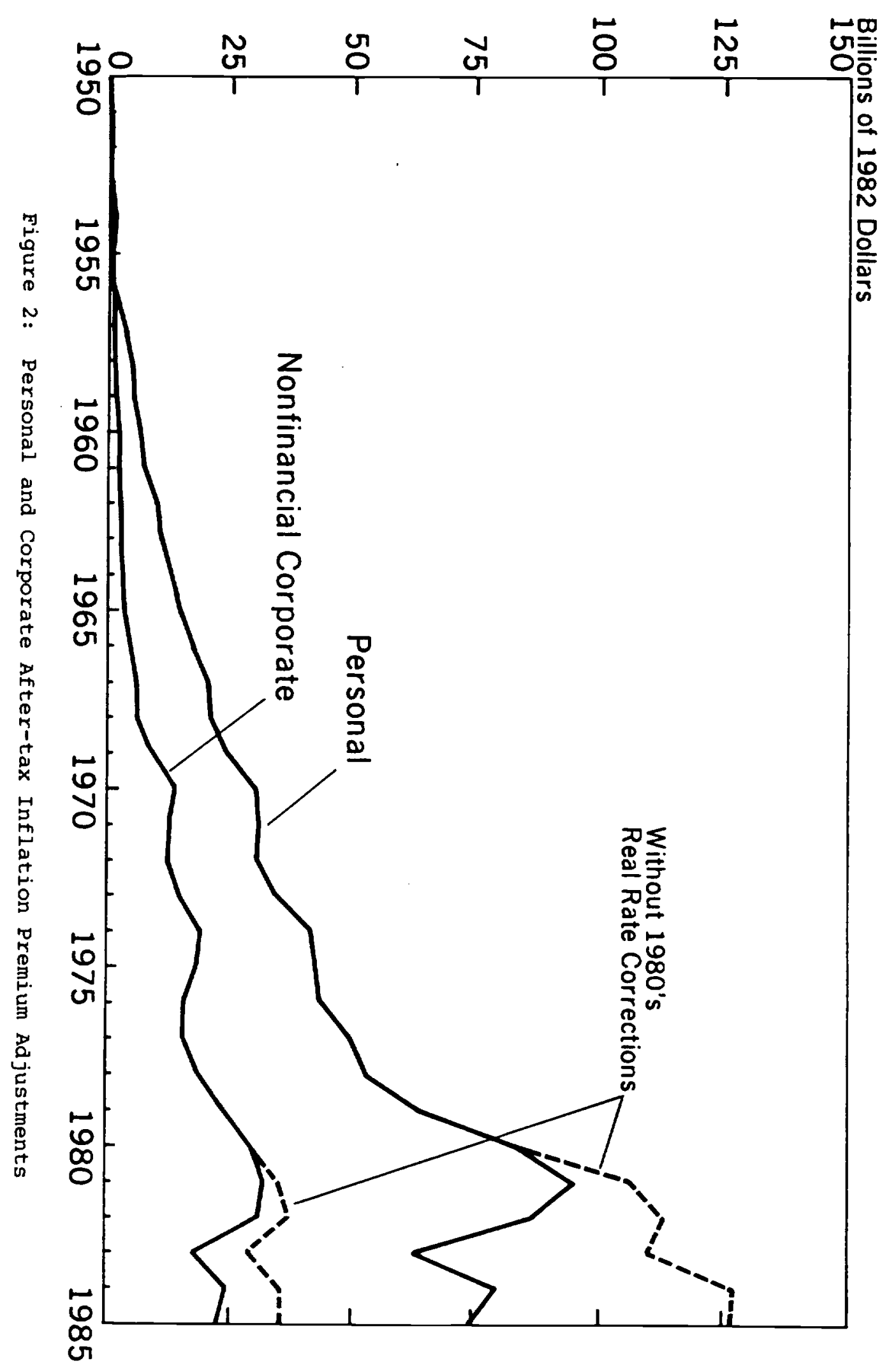




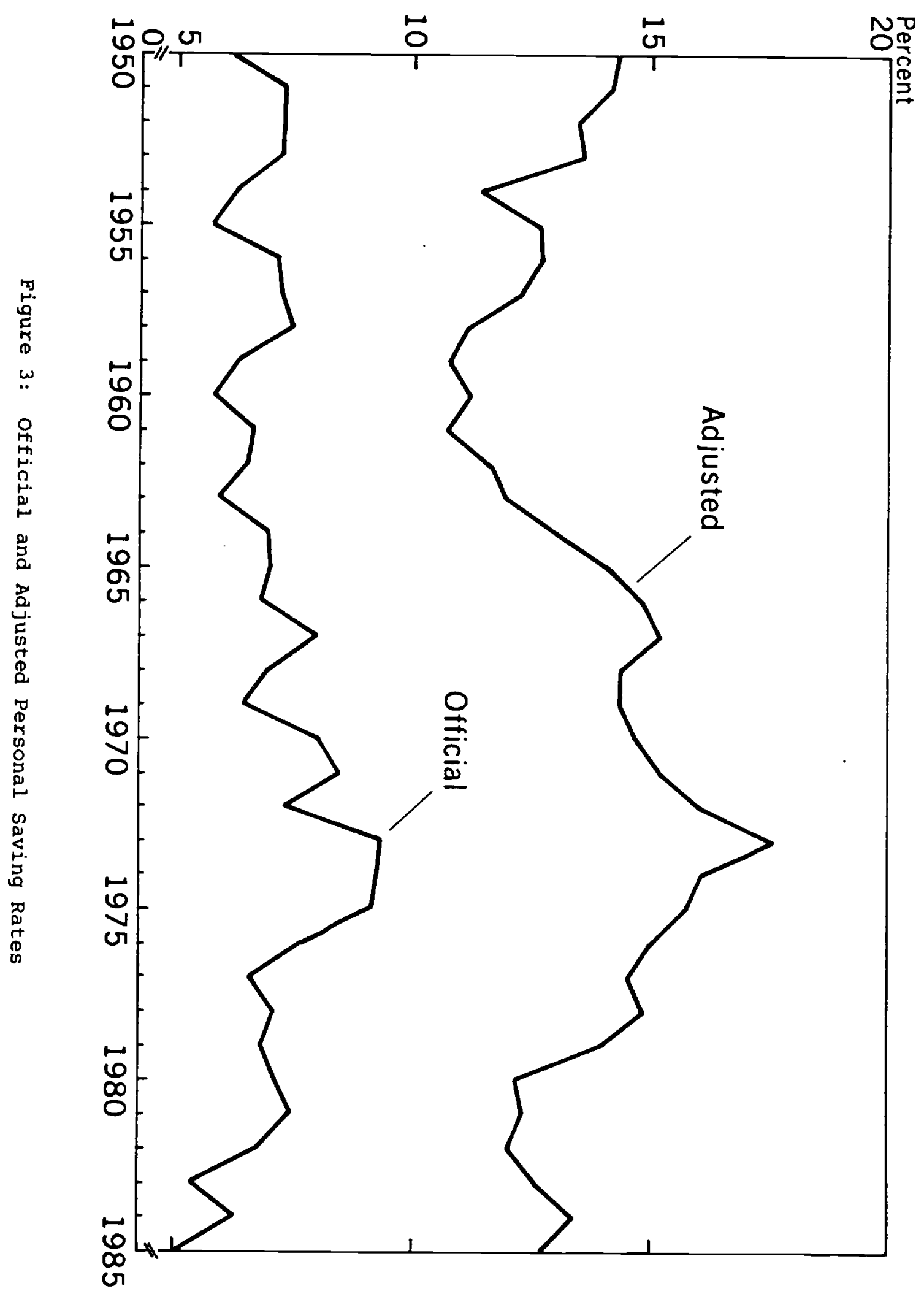




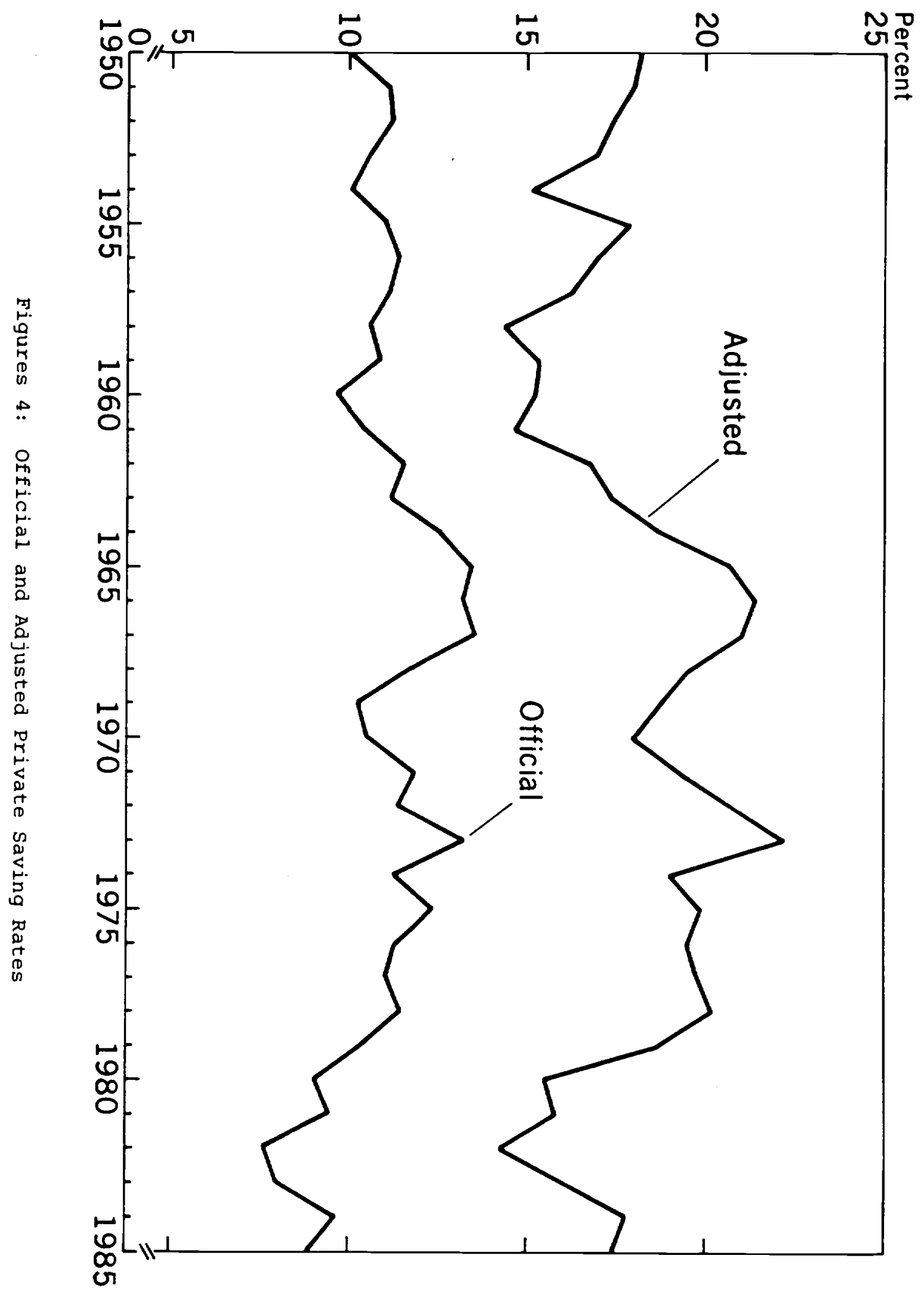




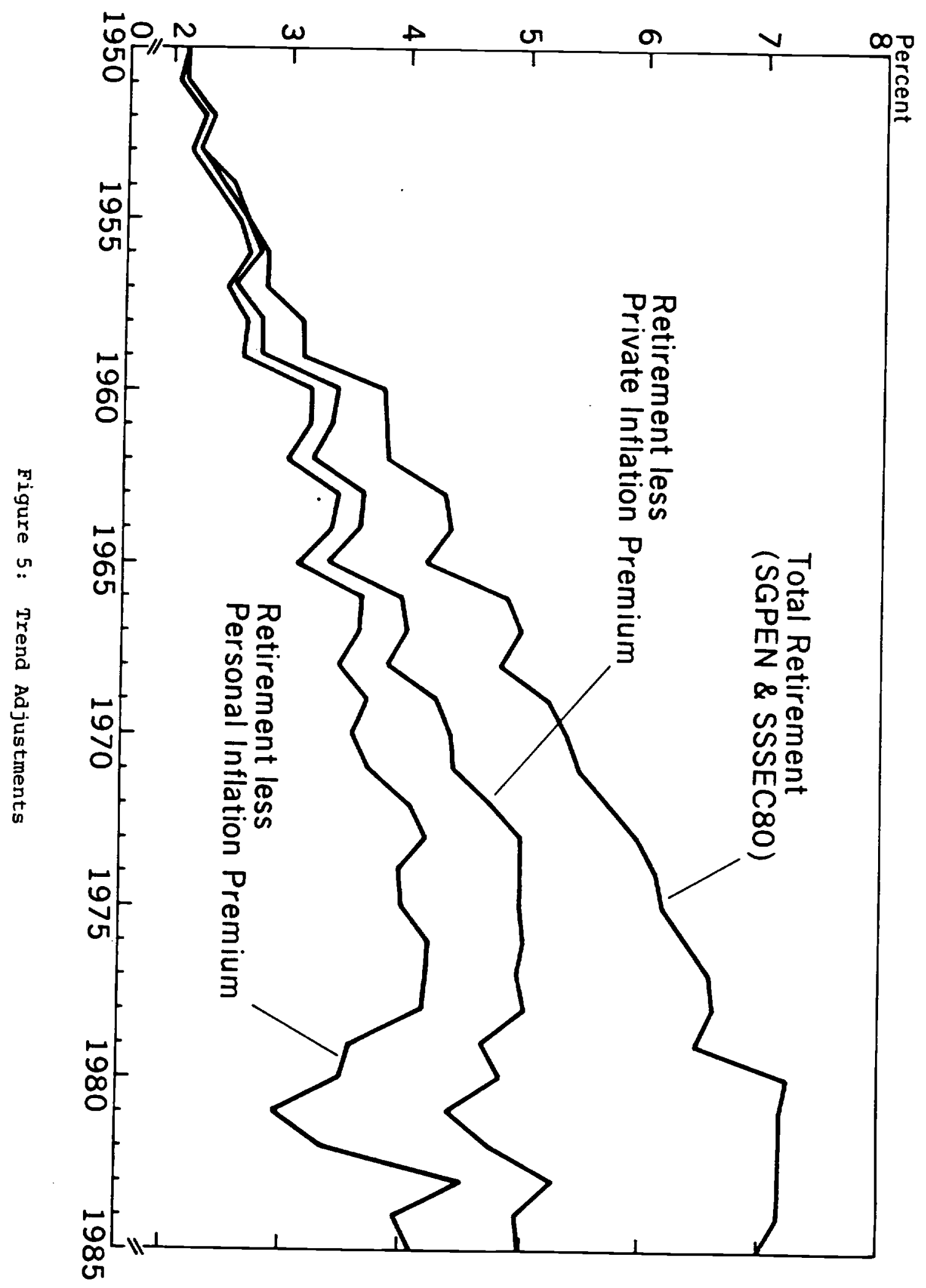




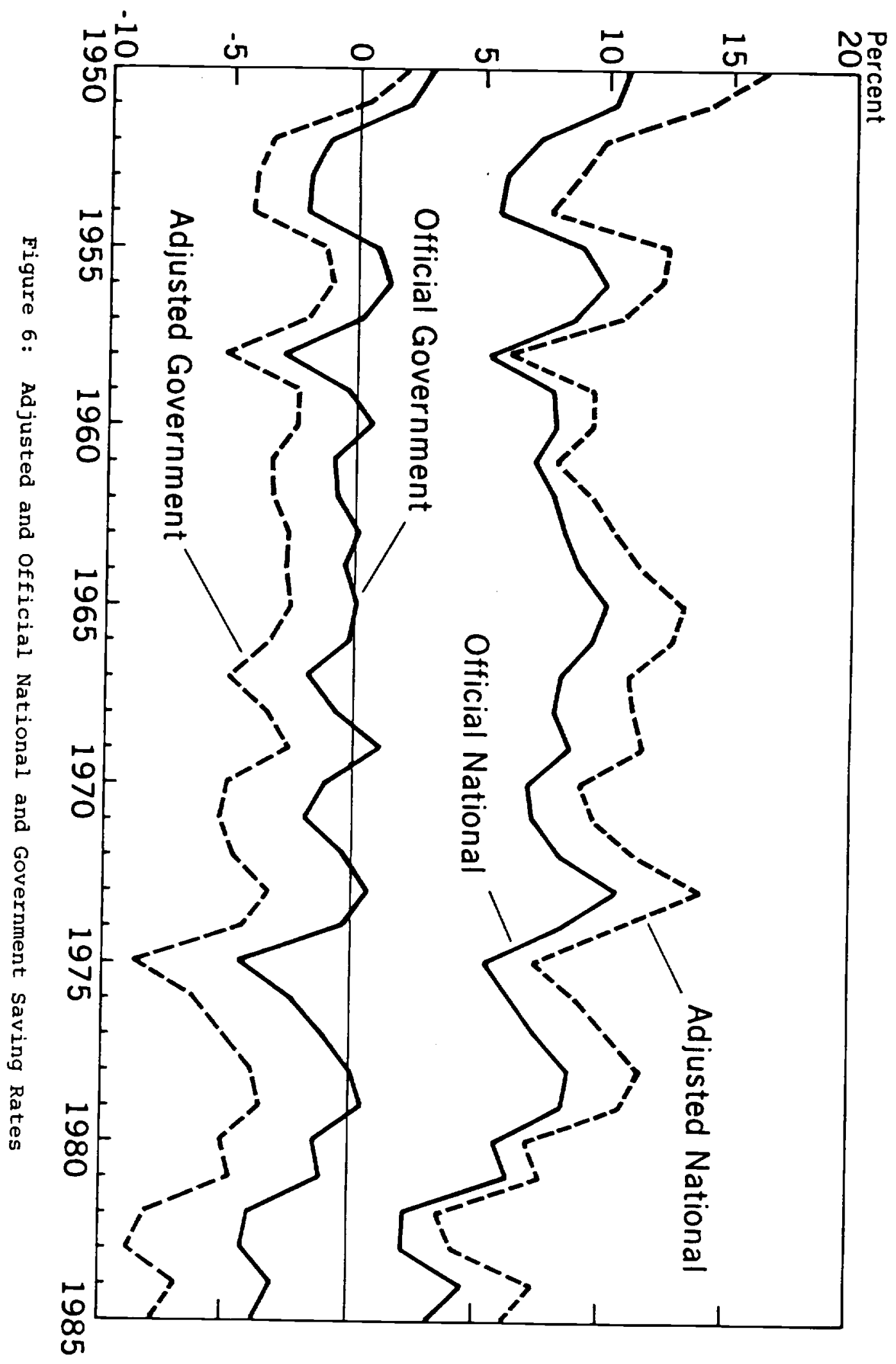




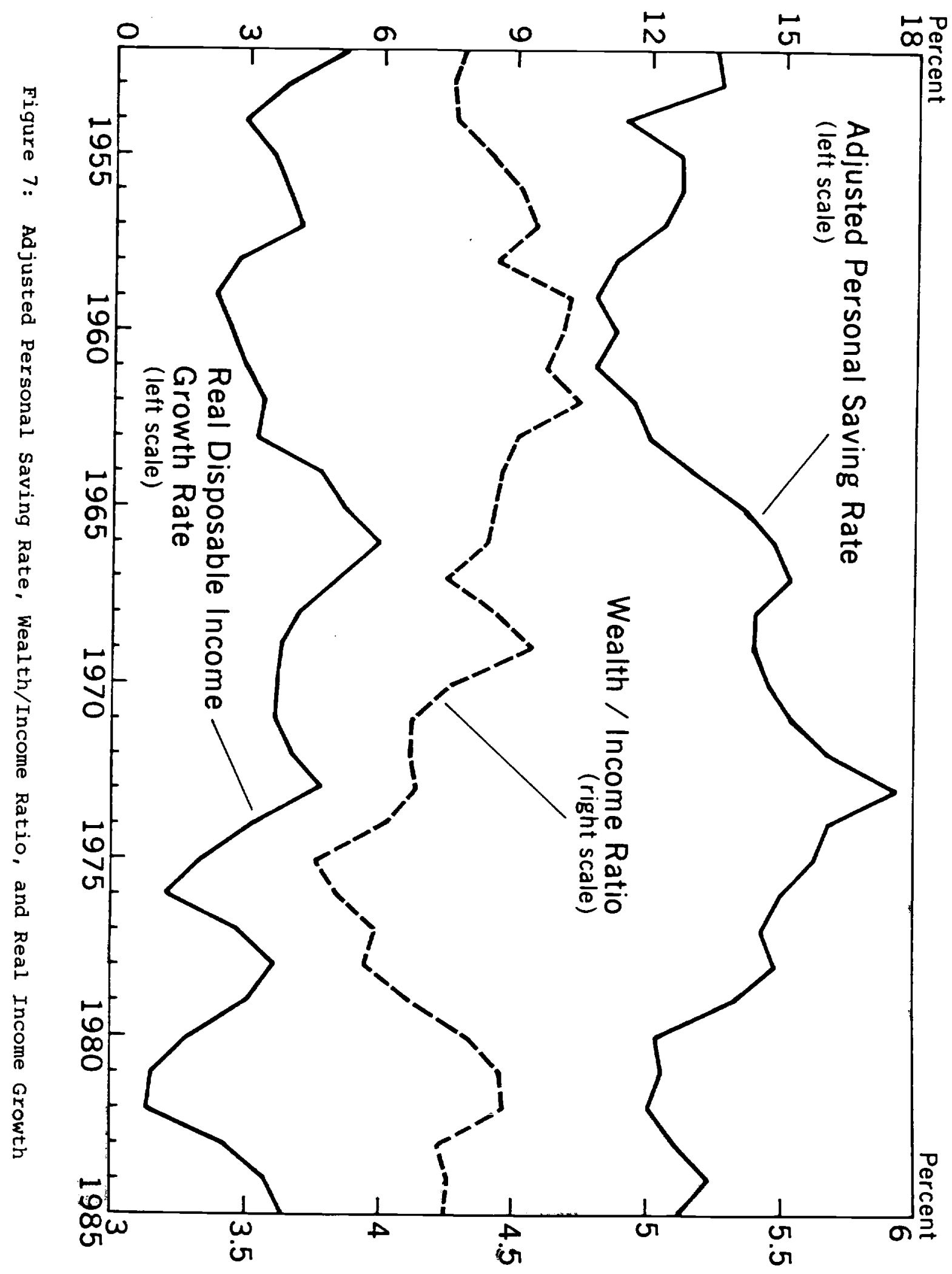

